\title{
Brain $\mathrm{CB}_{1}$ receptor expression following lipopolysaccharide- induced inflammation
}

\author{
Huangming $\mathrm{Hu}^{1,2}$, Winnie $\mathrm{Ho}^{2}$, Ken Mackie ${ }^{3}$, Quentin J. Pittman², and Keith A. Sharkey2, \\ ${ }^{1}$ Division of Gastroenterology, Department of Internal Medicine, Kaohsiung Medical University \\ Hospital, Kaohsiung Medical University, Kaohsiung 807, Taiwan \\ ${ }^{2}$ Hotchkiss Brain Institute and Department of Physiology and Pharmacology, University of \\ Calgary, Calgary, Alberta T2N 4N1, Canada \\ ${ }^{3}$ Department of Psychological and Brain Sciences, Gill Center for Biomolecular Science, Indiana \\ University, Bloomington, Indiana 47405,USA
}

\begin{abstract}
Cannabinoid 1 receptors $\left(\mathrm{CB}_{1}\right)$ are highly expressed on presynaptic terminals in the brain where they are importantly involved in the control of neurotransmitter release. Alteration of $\mathrm{CB}_{1}$ expression is associated with a variety of neurological and psychiatric disorders. There is now compelling evidence that peripheral inflammatory disorders are associated with depression and cognitive impairments. These can be modeled in rodents with peripheral administration of lipopolysaccharide (LPS), but central effects of this treatment remain to be fully elucidated. As a reduction in endocannabinoid tone is thought to contribute to depression, we asked whether the expression of $\mathrm{CB}_{1}$ in the central nervous system (CNS) is altered following LPS treatment. CD1 mice received LPS $(0.1-1 \mathrm{mg} / \mathrm{kg}$, ip) and 6 hours later activated microglial cells were observed only in circumventricular organs and only at the higher dose. At 24 hours, activated microglial cells were identified in other brain regions, including the hippocampus, a structure implicated in some mood disorders. Immunohistochemistry and real-time PCR were utilized to evaluate the change of $\mathrm{CB}_{1}$ expression 24 hours after inflammation. LPS induced an increase of $\mathrm{CB}_{1}$ mRNA in hippocampus and brainstem. Subsequent immunohistochemical analysis revealed reduced $\mathrm{CB}_{1}$ in hippocampus, especially in $\mathrm{CA} 3$ pyramidal layer. Analysis of co-localization with markers of excitatory and inhibitory terminals indicated that the decrease in $\mathrm{CB}_{1}$ expression was restricted to glutamatergic terminals. Despite widespread microglial activation, these results suggest that peripheral LPS treatment leads to limited changes in $\mathrm{CB}_{1}$ expression in the brain.
\end{abstract}

\footnotetext{
(C) 2012 IBRO. Published by Elsevier Ltd. All rights reserved.

*Corresponding author: Dr. Keith Sharkey, Department of Physiology \& Pharmacology, University of Calgary, 3330 Hospital Drive NW, Calgary, Alberta, T2N 4N1, Canada, Tel: 403-220-4601, Fax: 403-283-2700, ksharkey@ucalgary.ca.

Publisher's Disclaimer: This is a PDF file of an unedited manuscript that has been accepted for publication. As a service to our customers we are providing this early version of the manuscript. The manuscript will undergo copyediting, typesetting, and review of the resulting proof before it is published in its final citable form. Please note that during the production process errors may be discovered which could affect the content, and all legal disclaimers that apply to the journal pertain.

Disclosures

The authors have no conflicts of interest.

Author Contributions

HH, QJP \& KAS designed the studies; HH \& WH performed research; KM provided unique reagents; HH, WH, QJP \& KAS analyzed data and $\mathrm{HH}, \mathrm{WH}, \mathrm{KM}$, QJP \& KAS wrote and revised the article.
} 


\section{Keywords}

cannabinoids; hippocampus; lipopolysaccharide; microglial cells

\section{INTRODUCTION}

Innate immune responses to peripheral inflammation initiate a coordinated set of physiological, endocrine and behavioral responses orchestrated by the central nervous system (CNS). This occurs when inflammatory molecules such as lipopolysaccharide (LPS), a cell wall constituent of gram negative organisms, bind to Toll-like receptors on peripheral immune cells; these in turn produce a number of inflammatory mediators including complement, prostaglandins, and cytokines. These molecules signal to the brain to initiate the host defense response that includes fever, hypothalamic-pituitary-adrenal activation and sickness behavior (Blatteis, 2007). However, the neural response to inflammation is not limited to these acute innate immune responses; there is increasing evidence that there are longer lasting changes in the brain that continue after the initial inflammatory episode is resolved. These include changes in neuronal excitability (Riazi et al., 2008), as well as the appearance of depressive like behavior that can last $24 \mathrm{~h}$ or longer after the initial exposure to an acute dose of LPS (Dantzer et al., 2008). While the mechanisms for the long lasting response to LPS are not entirely elucidated, it is likely that they result from cytokines and other inflammatory molecules that are synthesized within the CNS, predominantly in microglia and astrocytes (Allan and Rothwell, 2001;Dantzer et al., 2008). Cytokines such as interleukin (IL)-1 $\beta$, IL-6 and tumor necrosis factor alpha (TNFa) have potent effects on neuronal excitability (Galic et al., 2012) and also alter enzymatic pathways to influence neurotransmitter synthesis (O'Connor et al., 2009). Although the brain regions responsible for the acute response to LPS and circulating cytokines are well established (Sagar et al., 1995;Day and Akil, 1996), those that mediate these longer term states are less well understood. However, it is likely that neurotransmitter pathways that are engaged during the acute responses may contribute to longer term effects.

The endocannabinoid system mediates part of the acute thermoregulatory and endocrine responses to LPS (Fraga et al., 2009;De Laurentiis et al., 2010;Steiner et al., 2011). It is of particular interest that a long term depressive like phenotype emerges after LPS, as a reduction in endocannabinoid tone is thought to contribute to anxiety and depression (Hill and Gorzalka, 2009; Parolaro et al., 2010). There is evidence that activation of the hypothalamic-pituitary-adrenal axis, which is also a prominent feature of the CNS response to LPS (Beishuizen and Thijs, 2003), causes rapid change in endocannabinoid content in the brain (Wang et al., 2012) and alteration in the expression of cannabinoid 1 receptors $\left(\mathrm{CB}_{1}\right)$ (Hill et al., 2009). This functional change can occur within 24 hours (Crosby et al., 2011), which would be compatible with the emergence of LPS induced depressive like behavior. Thus we hypothesized that acute administration of LPS will cause a persistent change in $\mathrm{CB}_{1}$ expression in areas of the brain important in emotional and cognitive function. As there is little information available as to the areas of mouse brain that are responsive to LPS, we correlated the extent of $\mathrm{CB}_{1}$ changes with microglial activation, an important component of the CNS response to LPS (Dantzer et al., 2008) that has not previously been examined in the mouse brain.

\section{EXPERIMENTAL PROCEDURES}

\section{Animals}

All the experimental procedures were carried out in accordance with the guidelines of the Canadian Council on Animal Care after approval from the Health Sciences Animal Care 
Committee of the University of Calgary. Male CD1 mice between 4 and 5 weeks of age were purchased from Charles River (Montreal, Quebec, Canada). Upon arrival, they were housed under specific pathogen free conditions on a 12-hour light-dark cycle with free access to food and water for one week before treatment. Male $\mathrm{CB}_{1}$-deficient mice $\left(\mathrm{CB}_{1}{ }^{--}\right)$ on a predominant C57BL/6N background were used at 5-8 weeks of age and genotyped as previously described (Marsicano et al., 2002).

CD1 mice were divided into 6 groups to the receive the following treatments: saline, LPS $0.1 \mathrm{mg} / \mathrm{kg}$ or $1 \mathrm{mg} / \mathrm{kg} 6 \mathrm{~h}$ prior to sacrifice, or the same treatments, $24 \mathrm{~h}$ prior to sacrifice. LPS (E. coli O26:B6, Sigma-Aldrich, St. Louis, MO, USA) was dissolved in sterile saline and injected intraperitoneally in a volume of $1 \mathrm{~mL} / \mathrm{kg}$ between 8 am and $10 \mathrm{am}$.

\section{Immunohistochemistry}

Animals were anesthetized with isoflurane, perfused intracardially with $20 \mathrm{ml}$ saline followed by $20 \mathrm{ml} 4 \%$ paraformaldehyde in phosphate buffered saline (PBS, pH 7.3). Brains were removed and fixed in $4 \%$ paraformaldehyde at $4{ }^{\circ} \mathrm{C}$ overnight, and then cryoprotected with $20 \%$ sucrose in PBS at $4^{\circ} \mathrm{C}$ overnight. Specimens were embedded in OCT compound (Tissue-Tek, Sakura Finetek Japan Co., Ltd., Tokyo, Japan) and were sectioned in the coronal plane on a cryostat $(40 \mu \mathrm{m})$. Several floating sections were collected with reference to the mouse brain atlas (Paxinos and Franklin, 1997) and contained nucleus accumbens (ACB, bregma $+1.1 \mathrm{~mm}$ ), organum vasculosum of the lamina terminalis (OVLT, bregma $+0.5 \mathrm{~mm}$ ), bed nucleus of the terminal stria terminalis (BNST, bregma $+0.26 \mathrm{~mm}$ ), subfornical organ (SFO, bregma $-0.58 \mathrm{~mm}$ ), amygdala and paraventricular nucleus (PVN) (bregma $-0.94 \mathrm{~mm}$ ), hippocampus (Hipp) and hypothalamus (bregma $-1.46 \mathrm{~mm}$ ), medial basal hypothalamus ( $\mathrm{MBH}$, bregma $-1.82 \mathrm{~mm}$ ), substantia nigra ( $\mathrm{SN}$, bregma $-3.28 \mathrm{~mm}$ ), nucleus of the solitary tract (NTS, bregma $-7.08 \mathrm{~mm}$ ) and area postrema (AP, bregma -7.48 $\mathrm{mm}$ ). Three consecutive sections from each coronal level were used for 3 different primary antibodies respectively: Iba-1, recognizing ionized calcium binding adaptor molecule 1 to label microglia (1:1000; Wako Pure Chemical Industries, Osaka, Japan)(Imai et al., 1996), rabbit anti- $\mathrm{CB}_{1} \mathrm{C}$-terminal antibody directly against the last 73 amino acid of rat $\mathrm{CB}_{1}$ receptor (1:1000)(Hajos et al., 2000) and rabbit anti-CB $\mathrm{CB}_{1} \mathrm{~N}$-terminal antibody directly against the first 77 amino acids of the rat $\mathrm{CB}_{1}$ receptor (1:1000)(Tsou et al., 1998). The $\mathrm{N}$ and $\mathrm{C}$-terminal protein sequences of $\mathrm{CB}_{1}$ used to raise the antibodies are identical in the rat and mouse (NCBI Reference Sequence database).

Floating sections were washed three times in 10 minute intervals in PBS containing $0.1 \%$ Triton X-100 and then incubated in blocking buffer comprised of PBS containing 10\% normal donkey serum for 1 hour at room temperature. Sections were then incubated in primary antibody at $4{ }^{\circ} \mathrm{C}$ for 48 hours. The specificity of both anti- $\mathrm{CB}_{1}$ antibodies was confirmed using brains from $\mathrm{CB}_{1}$ knockout mice, which showed no staining. The specificity of anti-CB $\mathrm{CB}_{1} \mathrm{~N}$-terminal antibody was also verified by incubation of sections from salinetreated $\mathrm{CD} 1$ mouse using antibody which was preabsorbed with the immunizing peptide for $24 \mathrm{~h}$ at $4^{\circ} \mathrm{C}(10 \mu \mathrm{g} / \mathrm{ml}$ in diluted antibody). This procedure completely abolished the labeling in cortex and hippocampus. Next, tissues were washed in PBS containing $0.1 \%$ Triton $\mathrm{X}-1003$ times for $10 \mathrm{~min}$ and then incubated in donkey anti-rabbit CY3 (1:100; \#711-166-152, Jackson ImmunoResearch Laboratories Inc., West Grove, PA, USA) at room temperature for $2 \mathrm{~h}$. Sections were mounted and observed using a Zeiss Axioplan fluorescence microscope (Carl Zeiss, Jena, Germany). The gray-scale images were captured by digital camera (Qimaging, Surrey, BC, Canada). An assessment of the density of CB1 immunoreactivity was carried out by an observer unaware of treatment conditions and scored on a 4 point scale as previously described (Suarez et al., 2008). 


\section{Quantification and colocalization of $\mathrm{CB}_{1}$ immunoreactivity in hippocampus}

In order to compare the distribution of $\mathrm{CB}_{1}$ in different neuronal populations in hippocampus, sections were incubated in a primary antibody mixture containing rabbit anti$\mathrm{CB}_{1} \mathrm{~N}$-terminal antibody (1:1000), guinea pig anti-vesicular glutamate transporter 1 (VGluT1) antibody (1:2500, \#AB5905, Chemicon international Inc., Temecula, CA, USA) and mouse anti-glutamate decarboxylase 65 (GAD65) antibody (1:200, \#G1166, SigmaAldrich Co. St. Louis, MO, USA). Single labeling of each antibody was performed prior to the triple labeling to verify that the pattern of immunoreactivity was identical to that revealed in the triple staining (data not shown). Following the same procedure as described above, sections were then incubated in a secondary antibody mixture comprising donkey anti-rabbit CY5 (1:100,\#111-175-008), donkey anti-guinea pig FITC (1:200, \#706-095-148) and donkey anti-mouse CY3 (1:200, \#715-165-150) (from Jackson ImmunoResearch Laboratories Inc.). High power field images of CA1 pyramidal and radiatum layer, as well as CA3 pyramidal layer, were captured using an Olympus FluoView 1000 confocal microscope using a $60 \mathrm{X}$ objective. Immunoreactivity of each antibody was analyzed by FV10-ASW2.1 software (Olympus Canada Inc., ON, Canada). The background intensity was measured as the average intensity from an area of interest selected from an adjacent region lacking immunoreactivity. The threshold for each antibody's immunoreactivity was determined from the background intensity of each image. The immunoreactivity was the quantified as percentage of pixels within a given area of interest having an intensity higher than the threshold.

The distribution of $\mathrm{CB}_{1}$ on different neuronal populations was determined by the colocalization of $\mathrm{CB}_{1}$ and either VGluT1 or GAD65 immunostaining. The confocal images were analyzed by Volocity software (PerkinElmer Inc., Waltham, MA, USA) which estimates colocalization by Manders' colocalization coefficients (Manders et al., 1993).

\section{Quantitative polymerase chain reaction (PCR)}

Animals were anaesthetized with isoflurane and perfused intracardially with $20 \mathrm{ml}$ saline. Brains were removed and microdissected into five regions (cortex, hippocampus, thalamus, hypothalamus and brainstem). Tissues were immediately stored in RNAlater (RNA Stabilization Reagent; QIAGEN, Mississauga, ON, Canada) at $-20^{\circ} \mathrm{C}$ before use. Total RNA was extracted using QIAGEN RNeasy Plus Mini Kit, and its concentration was determined by UV-spectrophotometer at $260 \mathrm{~nm}$, as previously described (Storr et al., 2009). cDNA was generated from 600 ng of total RNA using the High Capacity cDNA Reverse Transcription Kit (Applied Biosystems, Foster City, CA) immediately after extraction of total RNA. Mock reaction mixtures were run without reverse transcriptase buffer to detect genomic DNA contamination. TaqMan Gene Expression assay kits for $\mathrm{CB}_{1}$ (Mm00432621_s1) and TNFa (Mm00443258_m1) were purchased from Applied Biosystems, as well as rodent GAPDH probe (VIC / MGB probe), which was used as an internal standard. Triplicate samples of $20 \mathrm{ng}$ of each cDNA were amplified by ABI Prism 7900HT Sequence Detection System (Applied Biosystems, Foster City, CA). The cycling parameters were $50^{\circ} \mathrm{C}$ for $2 \mathrm{~min}, 95^{\circ} \mathrm{C}$ for $10 \mathrm{~min}, 40$ cycles of $95^{\circ} \mathrm{C}$ for $15 \mathrm{sec}$, and $60^{\circ} \mathrm{C}$ for $1 \mathrm{~min}$. The results were represented as relative quantification value to the calibrator by $\Delta \Delta \mathrm{CT}$ method and analyzed by RQ Manager 1.2 software (Applied Biosystems). The calibrator for $\mathrm{CB}_{1}$ and $\mathrm{TNFa}$ were chosen from the hypothalamus and hippocampus, respectively, of a saline-treated $\mathrm{CD} 1$ mouse. The $\mathrm{CB}_{1}$ mRNA expression of each region was demonstrated as the mean \pm SEM of the relative quantitative value and was adjusted as fold change compared with the hypothalamus $\left(\mathrm{CB}_{1}\right)$ or the hippocampus $(\mathrm{TNFa})$ of the control group. 


\section{Statistics}

Quantitative data were expressed as the mean \pm SEM and analyzed by unpaired $t$ test using GraphPad Prism 5 (GraphPad Software, San Diego, CA). P values $<0.05$ were considered significant.

\section{RESULTS}

We first performed immunohistochemistry focusing on activated microglial cells and observed their distribution and morphology over time; all analyses were carried out by an individual unaware of the treatment conditions. When CD1 mice were treated with $100 \mu \mathrm{g} /$ $\mathrm{kg}$ LPS and examined after $6 \mathrm{~h}$, the morphology of microglial cells in every region of the brain investigated was similar to saline-treated animals; we observed ramifying processes and small perikarya indicative of a resting state (Ladeby et al., 2005;Kettenmann et al., 2011). Twenty four hours after treatment, morphologic changes were observed in microglial cells located in the circumventricular organs (CVOs); perikarya were hypertrophic with short processes and were amoeboid in shape (Figure 1). The morphologic changes in CVOs that we observed are characteristic of the activated state (Kettenmann et al., 2011), were more obvious when mice were treated with $1 \mathrm{mg} / \mathrm{kg}$ LPS, but were still limited to CVOs $6 \mathrm{~h}$ after treatment. Twenty four hours after LPS treatment $(1 \mathrm{mg} / \mathrm{kg})$, these changes were seen not only in CVOs, but also throughout other areas of the brain. The morphological changes observed in microglial cells were most prominent in areas adjacent to the ventricles and/or CVOs, such as the nucleus of the solitary tract and MBH (Figure 2). Marked changes to microglia were also noted in the hippocampus (Figure 2). The number of microglial cells appeared higher in the hippocampus $24 \mathrm{~h}$ after treating animals with $1 \mathrm{mg} / \mathrm{kg}$ of LPS, similar to observations of Chung et al. (2010). These observations suggested that the LPS-induced immune responses elicited in the CNS are both dose- and time-dependent, and that the CNS immune response to peripheral inflammation involving microglia begins in the CVOs and extends throughout the brain over time.

To build on these morphological changes we then examined TNFa mRNA expression in hippocampus of both $1 \mathrm{mg} / \mathrm{kg}$ LPS- and saline-treated groups at $24 \mathrm{~h}$, as TNFa is a key signaling molecule involved in microglial activation (Nguyen et al., 2002;Rivest, 2003). The expression of TNFa mRNA in the inflamed group was 8.7 fold higher $(\mathrm{p}<0.05)$ than that measured in the control group (Figure 3A). Accordingly, we chose the $1 \mathrm{mg} / \mathrm{kg}$ dosage and $24 \mathrm{~h}$ observation time point as the model to evaluate the possible effect of peripheral inflammation on $\mathrm{CB}_{1}$ expression in CNS.

To assess the expression of the $\mathrm{CB}_{1}$ receptor, quantitative $\mathrm{PCR}$ and immunohistochemistry were used to examine changes of mRNA and protein expression, respectively. First, we measured the level of $\mathrm{CB}_{1}$ mRNA by real-time PCR in different brain regions (Figure 3B). In saline-treated mice, cortex and hippocampus had higher $\mathrm{CB}_{1}$ mRNA levels than thalamus, hypothalamus and brainstem. A similar trend was observed in the qualitative distribution of $\mathrm{CB}_{1}$ immunoreactivity (Table 1). Compared to the saline-treated mice, there was a significantly higher level of $\mathrm{CB}_{1}$ mRNA in the brainstem $(\mathrm{p}<0.05)$ and hippocampus $(\mathrm{p}<0.001)$ of LPS-treated mice.

Next, we used two antibodies targeting the different parts of the $\mathrm{CB}_{1}$ receptor (the intracellular $\mathrm{C}$-terminal and extracellular $\mathrm{N}$-terminal) to identify the distribution and change of $\mathrm{CB}_{1}$ expression (Table 1). In general, $\mathrm{CB}_{1}$ receptor immunoreactivity was found as a network of punctuate or fine fibers and terminals on or around neurons. In some cases immunoreactive neurons were observed. Consistent with previous studies in rats, some regions had denser staining than the others, such as cortex, hippocampus and amygdala (Figures 4 and 5). However, there were some differences in the pattern of staining between 
the two antibodies. First, immunoreactivity to the $\mathrm{CB}_{1} \mathrm{~N}$-terminal antibody was observed in some neuronal cell bodies, which was not seen with the $\mathrm{CB}_{1} \mathrm{C}$-terminal antibody. $\mathrm{CB}_{1} \mathrm{~N}$ terminal positive cells were distributed mostly in areas with dense fine fiber staining (Figure $4 \mathrm{E})$. This cytoplasmic immunostaining likely revealed an intracellular pool of $\mathrm{CB}_{1}$ receptors and was not included in our quantitative observations described below. In some regions, e.g. the BNST, there was relatively dense immunostaining revealed using the $\mathrm{CB}_{1} \mathrm{~N}$-terminal antibody (Figure 6A) in comparison with the sparser staining revealed by the $\mathrm{C}$-terminal antibody (Figure 5G). Interestingly, there was no immunoreactivity to either $\mathrm{CB}_{1}$ antibody within CVOs (Figures 4 and 5).

Table 1 illustrates the immunohistochemical findings from individual brain regions chosen because they have been previously shown to have an increase in expression of immediate early gene cFos, or $\triangle$ FosB after treatment with doses of LPS (Marvel et al., 2004;Frenois et al., 2007;Buijs et al., 2008;Park et al., 2008). Despite wide-spread activation of microglial cells in the LPS-treated group, $\mathrm{CB}_{1}$ immunoreactivity in the CNS did not vary significantly in most regions of the brain, that is, staining observed in cortex, thalamus and hypothalamus had a similar distribution and intensity in both the control and LPS-treated groups. There was decreased $\mathrm{CB}_{1} \mathrm{~N}$-terminal immunoreactivity in the dorsal part of BNST taken from LPS-treated animals, compared to saline-treated mice (Figure 6A-B). Similarly, a reduction in the previously abundant $\mathrm{CB}_{1}$ immunoreactivity was also observed in $\mathrm{CA} 1$ and $\mathrm{CA} 3$ regions of the hippocampus, in both pyramidal layers, as well as the radiatum layer of CA1 (Figure 6C-F).

In the negative controls, neither antibody showed immunoreactivity in the brains of $\mathrm{CB}_{1}$ knockout mice (Figure $6 \mathrm{G}$ for $\mathrm{CB}_{1} \mathrm{~N}$-terminal antibody). Similarly, the abundant $\mathrm{CB}_{1} \mathrm{~N}$ terminal antibody immunoreactivity in the section containing hippocampus from the control group, was abolished by preabsorption with the immunizing peptide (Figure $6 \mathrm{H}$ ).

In brainstem, despite the presence of $\mathrm{CB}_{1}$ receptor message, only the region around the $4^{\text {th }}$ ventricle and at the margin of the hypoglossal nucleus adjoining the dorsal motor nucleus of the vagus revealed weak immunoreactivity. This was observed in both control and LPStreated groups. The CVOs did not show $\mathrm{CB}_{1}$ immunoreactivity even after inflammation (Figures 4 and 5), despite an abundance of activated microglial cells in these regions.

As $\mathrm{CB}_{1}$ is present on both glutamatergic and GABAergic terminals (Kano et al., 2009), we investigated whether the decreased expression of $\mathrm{CB}_{1}$ receptor after LPS inflammation occurred preferentially on excitatory or inhibitory terminals. $\mathrm{CB}_{1}$, VGluT1 (a marker of glutamatergic terminals) and GAD65 (a marker of GABAergic terminals) antibodies revealed that, in the pyramidal layer of the hippocampus, GABAergic terminals were more abundant than glutamatergic terminals (Figure 7 and 8A). In the radiatum layer, this bias was reversed. After LPS treatment, the expression and pattern of VGluT1 and GAD65 immunoreactivities did not appear to change (Figures 7 and $8 \mathrm{~A}$ ). The quantitative analysis of $\mathrm{CB}_{1}$ immunoreactivity confirmed that in LPS-inflamed mice, there was a decrease of $\mathrm{CB}_{1}$ expression in both $\mathrm{CA} 1$ radiatum and CA3 pyramidal layers, with statistical significance in the latter region (Figure 8A, $\mathrm{n}=7$ in both LPS and control groups). In the CA1 pyramidal layer, $\mathrm{CB}_{1}$ immunoreactivity did not change in the LPS treated group (data not shown). We analyzed the extent of colocalization in both the CA1 radiatum layer and CA3 pyramidal layer. LPS treatment induced a statistically significant reduction in the extent of colocalization on glutamatergic neurons in the $\mathrm{CA} 3$ pyramidal layer $(30.1 \pm 3.1 \%$, control $(n=7)$ vs. $19.0 \pm 2.9 \%$, inflamed $(n=7), p<0.05)$ (Figures 7 and $8 B$ ). Because of the loss of $\mathrm{CB}_{1}$ on the glutamatergic terminals after inflammation, there is an increase in the proportion of $\mathrm{CB}_{1}$ on $\mathrm{GABAergic}$ terminals in this region $(67.3 \pm 4.6 \%$, control vs. $80.8 \pm 3.9 \%$, 
inflamed, $\mathrm{p}<0.05)$. In both $\mathrm{CA} 1$ pyramidal and radiatum layer, the $\mathrm{CB}_{1}$ distribution was similar in inflamed and control groups (data not shown).

\section{DISCUSSION}

Although the distribution of $\mathrm{CB}_{1}$ in rat brain has been well described, that in the mouse brain has received less attention (Cristino et al., 2006). Here, we report the widespread distribution of $\mathrm{CB}_{1}$ in the mouse brain and find that, for the most part, it resembles that which has been previously described for the rat (Suarez et al., 2008). In particular we find a pattern of immunoreactivity consistent with a localization on synaptic terminals. Twentyfour hours after peripheral administration of LPS, $\mathrm{CB}_{1}$ immunoreactivity was selectively reduced in a restricted number of specific brain regions. Several other studies have observed similar changes in $\mathrm{CB}_{1}$ immunoreactivity in response to different stimuli. For example, in chronic unpredictable stress there is a decrease in $\mathrm{CB}_{1}$ expression in hippocampus associated with an increase in glucocorticoid levels (Hill et al., 2005). Decreased $\mathrm{CB}_{1}$ expression has also been shown in chronic alcoholism and in chronic abuse of cannabinoid drugs (Basavarajappa and Hungund, 2002;McKinney et al., 2008). This was mainly due to receptor internalization caused by the increase of endocannabinoid level in CNS in response to alcohol administration and due to ligand-induced desensitization (Sim-Selley, 2003;Smith et al., 2010). A recent study has also shown that short-term (24 hour) food deprivation causes a functional down regulation of $\mathrm{CB}_{1}$ in the hypothalamus (Crosby et al., 2011).

The mechanism by which LPS alters $\mathrm{CB}_{1}$ expression is not known. However, there is evidence that LPS induced fever involves endocannabinoids (Fraga et al., 2009). Thus endocannabinoid production, most likely from microglial cells, but possibly also from neurons, may cause down regulation of $\mathrm{CB}_{1}$. In keeping with this possibility, in cultured neurons, $\mathrm{CB}_{1}$ agonists induced downregulation of the receptor within minutes to hours (Coutts et al., 2001; Martini et al., 2007;Straiker et al., 2012). Our findings, and those from other studies, suggest that the change in $\mathrm{CB}_{1}$ expression might be mediated by an increase in endocannabinoid released from activated microglial cells during inflammation.

Nevertheless, the widespread distribution of activated or primed microglial cells following LPS administration cannot explain that, in the current studies, modulation of $\mathrm{CB}_{1}$ expression was only observed in limited brain regions. The existence of regional differences in $\mathrm{CB}_{1}$ downregulation has been suggested by studies using autoradiographic techniques to determine $\mathrm{CB}_{1}$ binding capacity in the brain after chronic administration of delta 9tetrahydrocannabinol (THC), a pharmacologically active ingredient of cannabis (Romero et al., 1998;Breivogel et al., 1999). Interestingly, the decrease in $\mathrm{CB}_{1}$ expression was always observed more rapidly in the hippocampus compared with the other regions (Sim-Selley, 2003; Martin et al., 2004). A study by Romero et al. (1998) disclosed that the decrease in $\mathrm{CB}_{1}$ binding capacity appeared in hippocampus 24 hours after the first THC injection but not in the other regions. This is similar to the findings in the current study where the hippocampus was one of the two regions to show a decrease in $\mathrm{CB}_{1}$ immunoreactivity after LPS stimulation. However, the mechanism is still elusive. $\mathrm{CB}_{1}$ expression level in another region, the dorsal part of BNST, showed a similar change in our observation. The BNST integrates information from stress input pathways and subsequently regulates both stress output and reward pathways (Herman and Cullinan, 1997), and the cannabinoid system has been postulated as the basis of autoregulatory mechanisms via $\mathrm{CB}_{1}$ receptors (Solinas et al., 2007). It is still a question whether this decrease in $\mathrm{CB}_{1}$ immunoreactivity correlates to any adaptation of behavior during inflammation. It is also important to note that an interaction between neuroinflammation induced by LPS and endocannabinoid hydrolysis to prostaglandins in the brain has recently been revealed (Nomura et al., 2011). Whether this plays a role in the reduced $\mathrm{CB}_{1}$ expression has yet to be determined. 
In addition to these regional differences in cannabinoid receptor expression during inflammation, another interesting aspect provided by the present results is the dissociation observed between immunoreactivity and the mRNA level. In hippocampus, we found that peripheral LPS administration induced an increase in $\mathrm{CB}_{1}$ mRNA 24 hours later, which was opposite to the change observed in immunoreactivity. This dissociative change has been documented previously in chronic cannabinoid administration. During administration of THC, the decrease of the $\mathrm{CB}_{1}$ expression was not accompanied by a similar change in mRNA level (Romero et al., 1998). Similarly, in the study observing the recovery of $\mathrm{CB}_{1}$ receptor adaptation after cessation of long-term cannabinoid administration, the hippocampus had the lowest level of $\mathrm{CB}_{1}$ receptor protein, but the mRNA level was about 1.5 fold higher than control at the first day of cessation (Sim-Selley et al., 2006). These experiments suggest that the downregulation of $\mathrm{CB}_{1}$ expression does not seem to result from transcriptional regulation in chronic THC administration model, and the adaptive regulation occurs mainly at the protein level. Our findings of the discrepant change between protein and mRNA level suggested that peripheral inflammation might induce a similar pattern of adaptive regulation of $\mathrm{CB}_{1}$ receptors in the hippocampus.

Another region showing discrepancy is the brainstem which has similar change in $\mathrm{CB}_{1}$ mRNA level in response to LPS as hippocampus; however, in this region, $\mathrm{CB}_{1}$ immunoreactivity is scarce in both control and inflamed animals. $\mathrm{CB}_{1}$ has been functionally localized in brainstem, particularly the area postrema and the surrounding nuclei of the dorsal vagal complex, the nucleus of the solitary tract and dorsal motor nucleus of the vagus (Van Sickle et al., 2003; Suarez et al., 2010). However, these studies were carried out in ferret (Van Sickle et al., 2003) and rat (Suarez et al., 2010) and thus may reflect species differences. In our immunohistochemical study, there was only faint staining around the $4^{\text {th }}$ ventricle and at the margin of hypoglossal nucleus adjoining the dorsal motor nucleus of the vagus, similar to the finding from Suarez et al. (2010) in mouse brain, and it was hard to discern change after LPS stimulation. Furthermore, no $\mathrm{CB}_{1}$ immunoreactivity was found in the area postrema, or the other CVOs in the mouse brain in any group, despite of the existence of numerous activated microglial cells. Further studies are required to better understand the relationship between $\mathrm{CB}_{1}$ and microglial cells in the brain.

Through their presynaptic localization, $\mathrm{CB}_{1}$ are responsible for cannabinoid-dependent suppression of neurotransmission in the hippocampus, where it plays a role in the pathogenesis of some mood disorders (Jorge et al., 2007). It has been shown that both GABAergic and glutamatergic neuronal terminals express $\mathrm{CB}_{1}$ (Kano et al., 2009), in agreement with our observations of colocalization of $\mathrm{CB}_{1}$ and GAD65, and $\mathrm{CB}_{1}$ and VGluT 1 immunoreactivity in the hippocampus. We demonstrated a differential decrease of $\mathrm{CB}_{1}$ expression after LPS inflammation in these two types of neuronal terminals in the CA3 pyramidal layer. The decrease of $\mathrm{CB}_{1}$ expression was significant in glutamatergic nerve terminals; further investigation is necessary to understand the possible influence of this during peripheral inflammation. Furthermore, due to the variable degree of decreasing expression of $\mathrm{CB}_{1}$ on both subtypes of neurons, $\mathrm{CB}_{1}$ distribution significantly increased in GABAergic neurons in CA3 pyramidal layer in inflamed animals in comparison with the control ones. These studies represent the basis for functional work to understand the possible effects of these changes in mood and behavior, such as depressive like behaviors seen during peripheral inflammation.

In summary, our results suggest that peripheral inflammation influences the expression of $\mathrm{CB}_{1}$ in specific regions of the CNS. The discrepancy of change between immunoreactivity and $\mathrm{CB}_{1}$ mRNA expression suggests that the adaptation occurs at the protein level, and this change possibly comes from the increase of endocannabinoids, released from activated microglial cells. Why only specific brain regions are affected, however, remains to be 
determined. This decrease of $\mathrm{CB}_{1}$ expression might influence the functional endocannabinoid tone, as well as the release properties of both glutamatergic and GABAergic neurons in hippocampus. This novel finding suggests that the variation of $\mathrm{CB}_{1}$ expression might be involved in the change of neuronal activation in CNS, as well as depressive like behaviors following inflammation.

\section{Acknowledgments}

This project was funded by grants from the Canadian Institutes of Health Research (to QJP and KAS) and National Institutes of Health (grants DA11322 and DA21696 to KM). We would like to thank Mohammad Bashashati and Dr. Kamala D. Patel for assistance with the quantitative PCR. We also thank Nina Cluny for providing help in preparing the manuscript.

\section{Abbreviations}

ACB nucleus accumbens

Amyg amygdala

AP

area postrema

ACo

anterior cortical amygdaloid nucleus

ARC

arcuate hypothalamic nucleus

BLA

anterior part of basolateral amygdaloid nucleus

BMA

anterior part of basomedial amygdaloid nucleus

BNST

bed nucleus of the stria terminalis

CA1 field CA1 of hippocampus

CA3

field CA3 of hippocampus

CB cannabinoid

$\mathrm{CeC}$ capsular part of central amygdaloid nucleus

CNS central nervous system

CVOs circumventricular organs

DG dentate gyrus

DMH dorsomedial hypothalamic nucleus

DMN dorsal motor nucleus of the vagus

GAD65 glutamate decarboxylase 65

Hipp hippocampus

Iba-1 ionized calcium binding adaptor molecular 1

LH lateral hypothalamic nucleus

LPS lipopolysaccharide

LS lateral septal nucleus

MBH medial basal hypothalamus

ME median eminence

MnPO median preoptic nucleus

MPA medial preoptic area 
NTS nucleus of solitary tract

OVLT vascular organ of the lamina terminalis

PAG periaqueductal gray

PeV periventricular hypothalamic nucleus

PVN paraventricular hypothalamic nucleus

PVT paraventricular thalamic nucleus

SAL saline

SFO subfornical organ

SON supraoptic nucleus

SN substantia nigra

THC 9-tetrahydrocannabinol

TNFa tumor necrosis factor a

VGluT1 vesicular glutamate transporter 1

VMH ventromedial hypothalamic nucleus

VMPO ventromedial preoptic nucleus

12N hypoglossal nucleus

\section{References}

Allan SM, Rothwell NJ. Cytokines and acute neurodegeneration. Nat Rev Neurosci. 2001; 2:734-744. [PubMed: 11584311]

Basavarajappa BS, Hungund BL. Neuromodulatory role of the endocannabinoid signaling system in alcoholism: an overview. Prostaglandins Leukot Essent Fatty Acids. 2002; 66:287-299. [PubMed: 12052043]

Beishuizen A, Thijs LG. Endotoxin and the hypothalamo-pituitary-adrenal (HPA) axis. J Endotoxin Res. 2003; 9:3-24. [PubMed: 12691614]

Blatteis CM. The onset of fever: new insights into its mechanism. Prog Brain Res. 2007; 162:3-14. [PubMed: 17645911]

Breivogel CS, Childers SR, Deadwyler SA, Hampson RE, Vogt LJ, Sim-Selley LJ. Chronic delta9tetrahydrocannabinol treatment produces a time-dependent loss of cannabinoid receptors and cannabinoid receptor-activated G proteins in rat brain. J Neurochem. 1999; 73:2447-2459. [PubMed: 10582605]

Buijs RM, van d V, Garidou ML, Huitinga I, Escobar C. Spleen vagal denervation inhibits the production of antibodies to circulating antigens. PLoS One. 2008; 3:e3152. [PubMed: 18773078]

Chung DW, Yoo KY, Hwang IK, Kim DW, Chung JY, Lee CH, Choi JH, Choi SY, Youn HY, Lee IS, Won MH. Systemic administration of lipopolysaccharide induces cyclooxygenase- 2 immunoreactivity in endothelium and increases microglia in the mouse hippocampus. Cell Mol Neurobiol. 2010; 30:531-541. [PubMed: 19908141]

Coutts AA, Anavi-Goffer S, Ross RA, MacEwan DJ, Mackie K, Pertwee RG, Irving AJ. Agonistinduced internalization and trafficking of cannabinoid CB1 receptors in hippocampal neurons. $\mathrm{J}$ Neurosci. 2001; 21:2425-2433. [PubMed: 11264316]

Cristino L, De Petrocellis L, Pryce G, Baker D, Guglielmotti V, Di Marzo V. Immunohistochemical localization of cannabinoid type 1 and vanilloid transient receptor potential vanilloid type 1 receptors in the mouse brain. Neuroscience. 2006; 139:1405-1415. [PubMed: 16603318]

Crosby KM, Inoue W, Pittman QJ, Bains JS. Endocannabinoids gate state-dependent plasticity of synaptic inhibition in feeding circuits. Neuron. 2011; 71:529-541. [PubMed: 21835348] 
Dantzer R, O'Connor JC, Freund GG, Johnson RW, Kelley KW. From inflammation to sickness and depression: when the immune system subjugates the brain. Nat Rev Neurosci. 2008; 9:46-56. [PubMed: 18073775]

Day HE, Akil H. Differential pattern of c-fos mRNA in rat brain following central and systemic administration of interleukin-1-beta: implications for mechanism of action. Neuroendocrinology. 1996; 63:207-218. [PubMed: 8677009]

De Laurentiis A, Fernandez-Solari J, Mohn C, Burdet B, Zorrilla Zubilete MA, Rettori V. The hypothalamic endocannabinoid system participates in the secretion of oxytocin and tumor necrosis factor-alpha induced by lipopolysaccharide. J Neuroimmunol. 2010; 221:32-41. [PubMed: 20207018]

Fraga D, Zanoni CI, Rae GA, Parada CA, Souza GE. Endogenous cannabinoids induce fever through the activation of CB1 receptors. Br J Pharmacol. 2009; 157:1494-1501. [PubMed: 19681872]

Frenois F, Moreau M, O'Connor J, Lawson M, Micon C, Lestage J, Kelley KW, Dantzer R, Castanon $\mathrm{N}$. Lipopolysaccharide induces delayed FosB/DeltaFosB immunostaining within the mouse extended amygdala, hippocampus and hypothalamus, that parallel the expression of depressivelike behavior. Psychoneuroendocrinology. 2007; 32:516-531. [PubMed: 17482371]

Galic MA, Riazi K, Pittman QJ. Cytokines and brain excitability. Front Neuroendocrinol. 2012; 33:116-125. [PubMed: 22214786]

Hajos N, Katona I, Naiem SS, Mackie K, Ledent C, Mody I, Freund TF. Cannabinoids inhibit hippocampal GABAergic transmission and network oscillations. Eur J Neurosci. 2000; 12:3239_ 3249. [PubMed: 10998107]

Herman JP, Cullinan WE. Neurocircuitry of stress: central control of the hypothalamopituitaryadrenocortical axis. Trends Neurosci. 1997; 20:78-84. [PubMed: 9023876]

Hill MN, Gorzalka BB. The endocannabinoid system and the treatment of mood and anxiety disorders. CNS Neurol Disord Drug Targets. 2009; 8:451-458. [PubMed: 19839936]

Hill MN, Hunter RG, McEwen BS. Chronic stress differentially regulates cannabinoid CB1 receptor binding in distinct hippocampal subfields. Eur J Pharmacol. 2009; 614:66-69. [PubMed: 19426726]

Hill MN, Patel S, Carrier EJ, Rademacher DJ, Ormerod BK, Hillard CJ, Gorzalka BB. Downregulation of endocannabinoid signaling in the hippocampus following chronic unpredictable stress. Neuropsychopharmacology. 2005; 30:508-515. [PubMed: 15525997]

Imai Y, Ibata I, Ito D, Ohsawa K, Kohsaka S. A novel gene iba1 in the major histocompatibility complex class III region encoding an EF hand protein expressed in a monocytic lineage. Biochem Biophys Res Commun. 1996; 224:855-862. [PubMed: 8713135]

Jorge RE, Acion L, Starkstein SE, Magnotta V. Hippocampal volume and mood disorders after traumatic brain injury. Biol Psychiatry. 2007; 62:332-338. [PubMed: 17123480]

Kano M, Ohno-Shosaku T, Hashimotodani Y, Uchigashima M, Watanabe M. Endocannabinoidmediated control of synaptic transmission. Physiol Rev. 2009; 89:309-380. [PubMed: 19126760]

Kettenmann H, Hanisch UK, Noda M, Verkhratsky A. Physiology of microglia. Physiol Rev. 2011; 91:461-553. [PubMed: 21527731]

Ladeby R, Wirenfeldt M, Garcia-Ovejero D, Fenger C, Dissing-Olesen L, Dalmau I, Finsen B. Microglial cell population dynamics in the injured adult central nervous system. Brain Res Brain Res Rev. 2005; 48:196-206. [PubMed: 15850658]

Manders EMM, Verbeek FJ, Aten JA. Measurement of co-localization of objects in dualcolour confocal images. Journal of Microscopy. 1993; 169:375-382.

Marsicano G, Wotjak CT, Azad SC, Bisogno T, Rammes G, Cascio MG, Hermann H, Tang J, Hofmann C, Zieglgansberger W, Di Marzo V, Lutz B. The endogenous cannabinoid system controls extinction of aversive memories. Nature. 2002; 418:530-534. [PubMed: 12152079]

Martin BR, Sim-Selley LJ, Selley DE. Signaling pathways involved in the development of cannabinoid tolerance. Trends Pharmacol Sci. 2004; 25:325-330. [PubMed: 15165748]

Martini L, Waldhoer M, Pusch M, Kharazia V, Fong J, Lee JH, Freissmuth C, Whistler JL. Ligandinduced down-regulation of the cannabinoid 1 receptor is mediated by the G-protein- coupled receptor-associated sorting protein GASP1. FASEB J. 2007; 21:802-811. [PubMed: 17197383] 
Marvel FA, Chen CC, Badr N, Gaykema RP, Goehler LE. Reversible inactivation of the dorsal vagal complex blocks lipopolysaccharide-induced social withdrawal and c-Fos expression in central autonomic nuclei. Brain Behav Immun. 2004; 18:123-134. [PubMed: 14759590]

McKinney DL, Cassidy MP, Collier LM, Martin BR, Wiley JL, Selley DE, Sim-Selley LJ. Doserelated differences in the regional pattern of cannabinoid receptor adaptation and in vivo tolerance development to delta9-tetrahydrocannabinol. J Pharmacol Exp Ther. 2008; 324:664-673. [PubMed: 17967938]

Nomura DK, Morrison BE, Blankman JL, Long JZ, Kinsey SG, Marcondes MCG, Ward AM, Hahn YK, Lichtman AH, Conti B, Cravatt BF. Endocannabinoid hydrolysis generates brain prostaglandins that promote neuroinflammation. Science. 2011; 33:809-813. [PubMed: 22021672]

Nguyen MD, Julien JP, Rivest S. Innate immunity: the missing link in neuroprotection and neurodegeneration? Nat Rev Neurosci. 2002; 3:216-227. [PubMed: 11994753]

O'Connor JC, Andre C, Wang Y, Lawson MA, Szegedi SS, Lestage J, Castanon N, Kelley KW, Dantzer R. Interferon-gamma and tumor necrosis factor-alpha mediate the upregulation of indoleamine 2,3-dioxygenase and the induction of depressive-like behavior in mice in response to bacillus Calmette-Guerin. J Neurosci. 2009; 29:4200-4209. [PubMed: 19339614]

Park SM, Gaykema RP, Goehler LE. How does immune challenge inhibit ingestion of palatable food? Evidence that systemic lipopolysaccharide treatment modulates key nodal points of feeding neurocircuitry. Brain Behav Immun. 2008; 22:1160-1172. [PubMed: 18562160]

Parolaro D, Realini N, Vigano D, Guidali C, Rubino T. The endocannabinoid system and psychiatric disorders. Exp Neurol. 2010; 224:3-14. [PubMed: 20353783]

Riazi K, Galic MA, Kuzmiski JB, Ho W, Sharkey KA, Pittman QJ. Microglial activation and TNFalpha production mediate altered CNS excitability following peripheral inflammation. Proc Natl Acad Sci U S A. 2008; 105:17151-17156. [PubMed: 18955701]

Rivest S. Molecular insights on the cerebral innate immune system. Brain Behav Immun. 2003; 17:1319. [PubMed: 12615045]

Romero J, Berrendero F, Manzanares J, Perez A, Corchero J, Fuentes JA, Fernandez-Ruiz JJ, Ramos JA. Time-course of the cannabinoid receptor down-regulation in the adult rat brain caused by repeated exposure to delta9-tetrahydrocannabinol. Synapse. 1998; 30:298-308. [PubMed: 9776133]

Sagar SM, Price KJ, Kasting NW, Sharp FR. Anatomic patterns of Fos immunostaining in rat brain following systemic endotoxin administration. Brain Res Bull. 1995; 36:381-392. [PubMed: 7712198]

Sim-Selley LJ. Regulation of cannabinoid CB1 receptors in the central nervous system by chronic cannabinoids. Crit Rev Neurobiol. 2003; 15:91-119. [PubMed: 14977366]

Sim-Selley LJ, Schechter NS, Rorrer WK, Dalton GD, Hernandez J, Martin BR, Selley DE. Prolonged recovery rate of $\mathrm{CB} 1$ receptor adaptation after cessation of long-term cannabinoid administration. Mol Pharmacol. 2006; 70:986-996. [PubMed: 16760363]

Smith TH, Sim-Selley LJ, Selley DE. Cannabinoid CB1 receptor-interacting proteins: novel targets for central nervous system drug discovery? Br J Pharmacol. 2010; 160:454-466. [PubMed: 20590557]

Solinas M, Yasar S, Goldberg SR. Endocannabinoid system involvement in brain reward processes related to drug abuse. Pharmacol Res. 2007; 56:393-405. [PubMed: 17936009]

Steiner AA, Molchanova AY, Dogan MD, Patel S, Petervari E, Balasko M, Wanner SP, Eales J, Oliveira DL, Gavva NR, Almeida MC, Szekely M, Romanovsky AA. The hypothermic response to bacterial lipopolysaccharide critically depends on brain CB1, but not CB2 or TRPV1, receptors. J Physiol. 2011; 589:2415-2431. [PubMed: 21486787]

Storr MA, Keenan CM, Zhang H, Patel KD, Makriyannis A, Sharkey KA. Activation of the cannabinoid 2 receptor (CB2) protects against experimental colitis. Inflamm Bowel Dis. 2009; 15:1678-1685. [PubMed: 19408320]

Straiker A, Wager-Miller J, Mackie K. The CB1 cannabinoid receptor C-terminus regulates receptor desensitization in autaptic hippocampal neurones. Br J Pharmacol. 2012; 165:2652-2659. [PubMed: 22014214] 
Suarez J, Bermudez-Silva FJ, Mackie K, Ledent C, Zimmer A, Cravatt BF, De Fonseca FR. Immunohistochemical description of the endogenous cannabinoid system in the rat cerebellum and functionally related nuclei. J Comp Neurol. 2008; 509:400-421. [PubMed: 18521853]

Suarez J, Romero-Zerbo SY, Rivera P, Bermudez-Silva FJ, Perez J, De Fonseca FR, FernandezLlebrez P. Endocannabinoid system in the adult rat circumventricular areas: an immunohistochemical study. J Comp Neurol. 2010; 518:3065-3085. [PubMed: 20533360]

Tsou K, Brown S, Sanudo-Pena MC, Mackie K, Walker JM. Immunohistochemical distribution of cannabinoid CB1 receptors in the rat central nervous system. Neuroscience. 1998; 83:393-411. [PubMed: 9460749]

Van Sickle MD, Oland LD, Mackie K, Davison JS, Sharkey KA. Delta9-tetrahydrocannabinol selectively acts on $\mathrm{CB} 1$ receptors in specific regions of dorsal vagal complex to inhibit emesis in ferrets. Am J Physiol Gastrointest Liver Physiol. 2003; 285:G566-G576. [PubMed: 12791597]

Wang M, Hill MN, Zhang L, Gorzalka BB, Hillard CJ, Alger BE. Acute restraint stress enhances hippocampal endocannabinoid function via glucocorticoid receptor activation. J Psychopharmacol. 2012; 26:56-70. [PubMed: 21890595] 


\section{HIGHLIGHTS}

Brain $\mathrm{CB}_{1}$ receptor expression following lipopolysaccharide-induced inflammation

Lipopolysaccharide (LPS) activates microglial cells in a region, time and dose-dependent manner

LPS induced an increase of $\mathrm{CB}_{1}$ mRNA in hippocampus and brainstem

LPS treatment reduced $\mathrm{CB}_{1}$ immunoreactivity in the $\mathrm{CA} 3$ pyramidal layer of the hippocampus

Reduced $\mathrm{CB}_{1}$ expression was largely restricted to glutamatergic terminals

Peripheral LPS treatment leads to limited changes in $\mathrm{CB}_{1}$ expression in the brain 

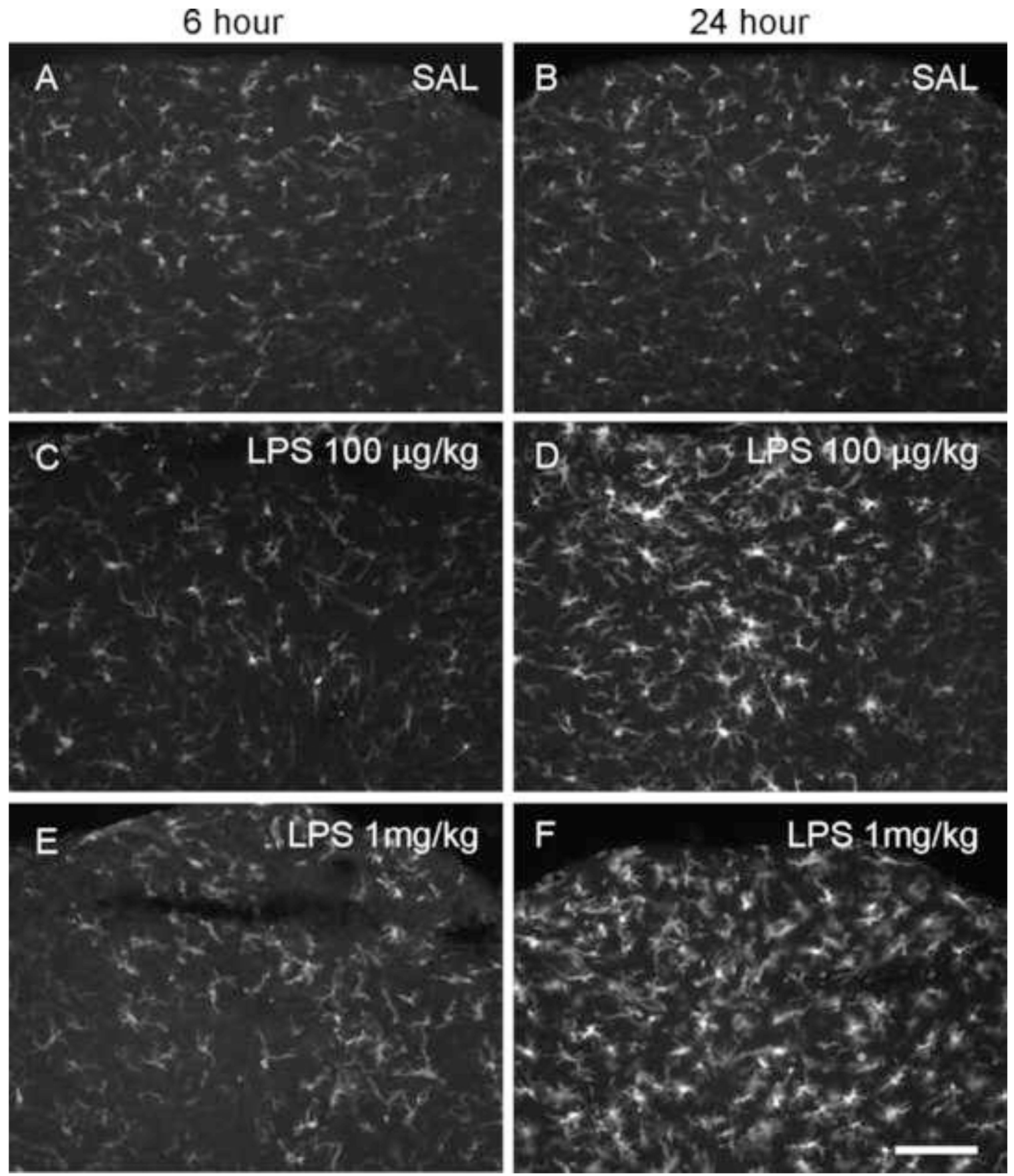

Figure 1.

Iba-1 immunoreactive microglial cells in area postrema. CD1 Mice were treated with an intraperitoneal injection of saline (SAL; A, B), $100 \mu \mathrm{g} / \mathrm{kg}$ lipopolysaccharide (LPS; C, D) or $1 \mathrm{mg} / \mathrm{kg}$ (E, F) LPS and were sacrificed 6 or $24 \mathrm{~h}$ after injection. In $100 \mu \mathrm{g} / \mathrm{kg}$ group, the activated microglial cells were found at $24 \mathrm{~h}$ after treatment (D). But in $1 \mathrm{mg} / \mathrm{kg}$ group, the change of morphology started at $6 \mathrm{~h}(\mathrm{E})$ and it was more prominent $24 \mathrm{~h}$ after treatment $(\mathrm{F})$. Scale bar: $100 \mu \mathrm{m}$. 

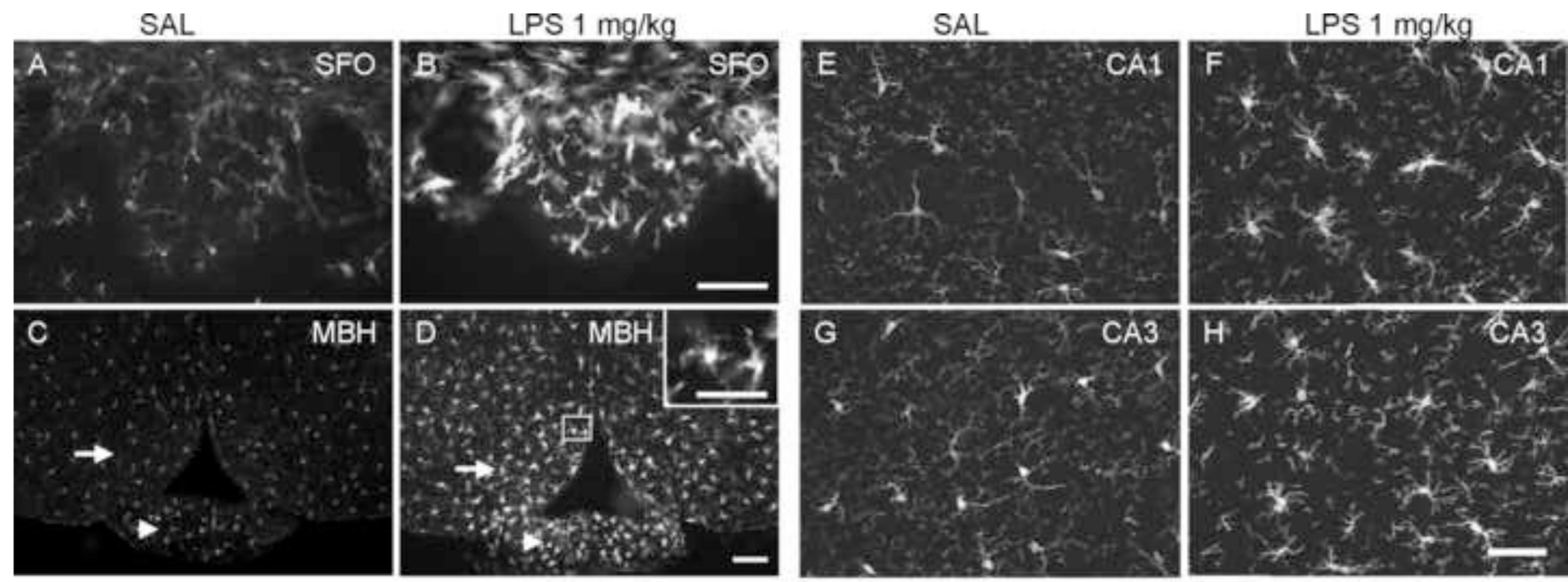

Figure 2.

Iba-1 immunoreactive microglial cells in different brain regions $24 \mathrm{~h}$ after saline (SAL) or LPS treatment ( $1 \mathrm{mg} / \mathrm{kg}$, i.p.). Activated microglial cells were found in CVOs (A, B, subfornical organ [SFO]; C, D, median eminence [arrow heads]) in LPS treated mice. Other brain regions also had microglial cells sporadically showing enlarged perikarya and thick processes with multiple branches (illustrated as the insert in panel D), such as arcuate hypothalamic nucleus ( $\mathrm{C}$ and $\mathrm{D}$; arrows) and hippocampus (E \& F, CA1; G \& H, CA3). (MBH, medial basal hypothalamus). Scale bar: $100 \mu \mathrm{m}$, insert in panel D: $50 \mu \mathrm{m}$. 


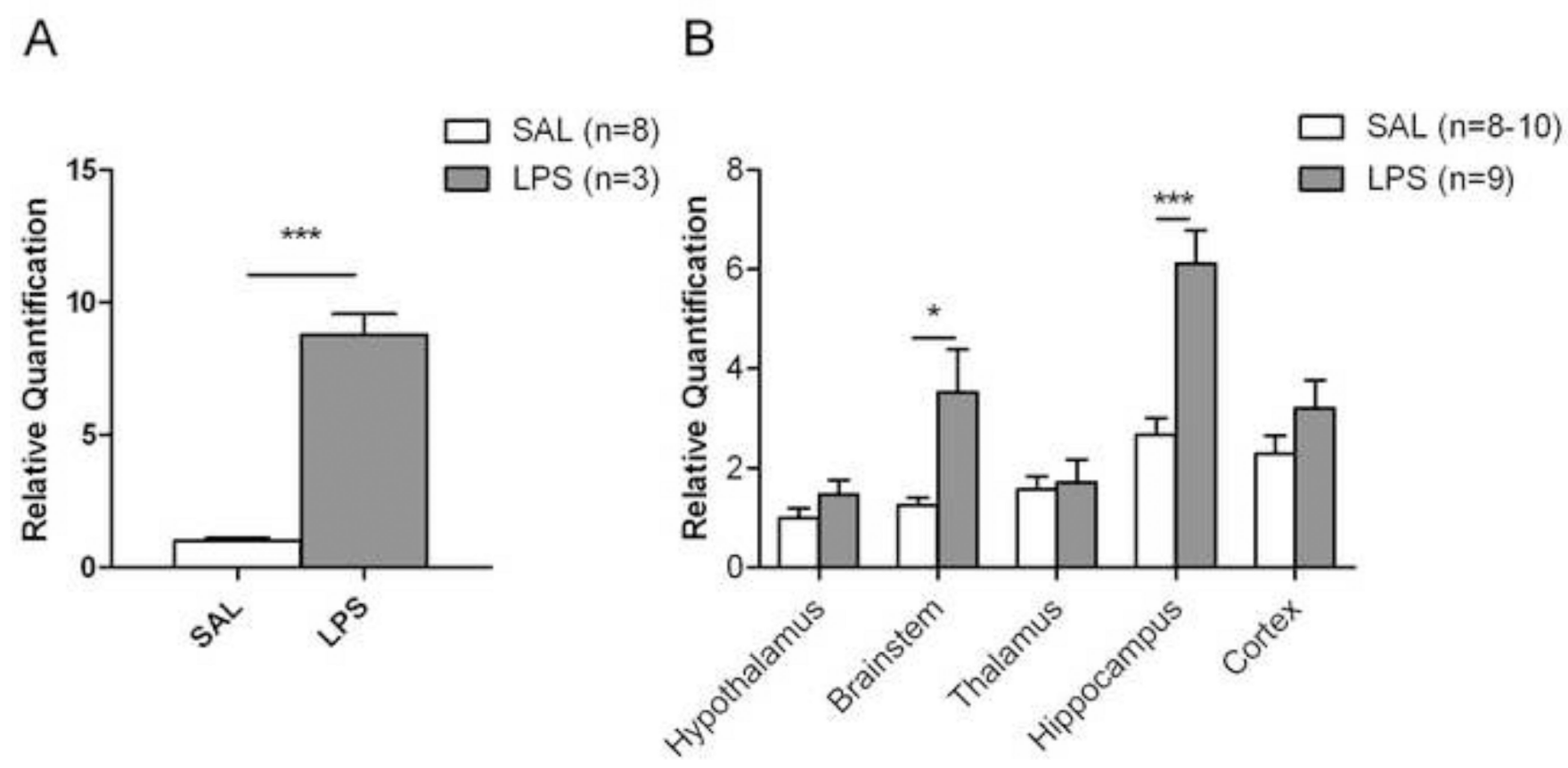

Figure 3.

Peripheral inflammation influences the expression of TNFa and $\mathrm{CB}_{1}$ mRNA in the brain. (A) Twenty four hours after saline ( $\mathrm{n}=8$ ) or LPS treatment ( $1 \mathrm{mg} / \mathrm{kg}$, i.p.; $\mathrm{n}=3)$, TNFa mRNA expression in hippocampus increased significantly in the treated group. (B) $\mathrm{CB}_{1}$ mRNA expression increased in brainstem and hippocampus of LPS-treated animals $(n=9)$ compared to saline-treated controls $(n=8-10)$. The transcripts of $\mathrm{TNFa}$ and $\mathrm{CB}_{1}$ were measured by real-time PCR using $\Delta \Delta \mathrm{CT}$ method. The relative quantification result is represented as mean \pm SEM, and adjusted by folds relative to a control group, which was hippocampus of SAL group in TNFa and hypothalamus of SAL group for $\mathrm{CB}_{1}$, respectively. ${ }^{*} \mathrm{p}<0.05, * * * \mathrm{p}<0.001$. 

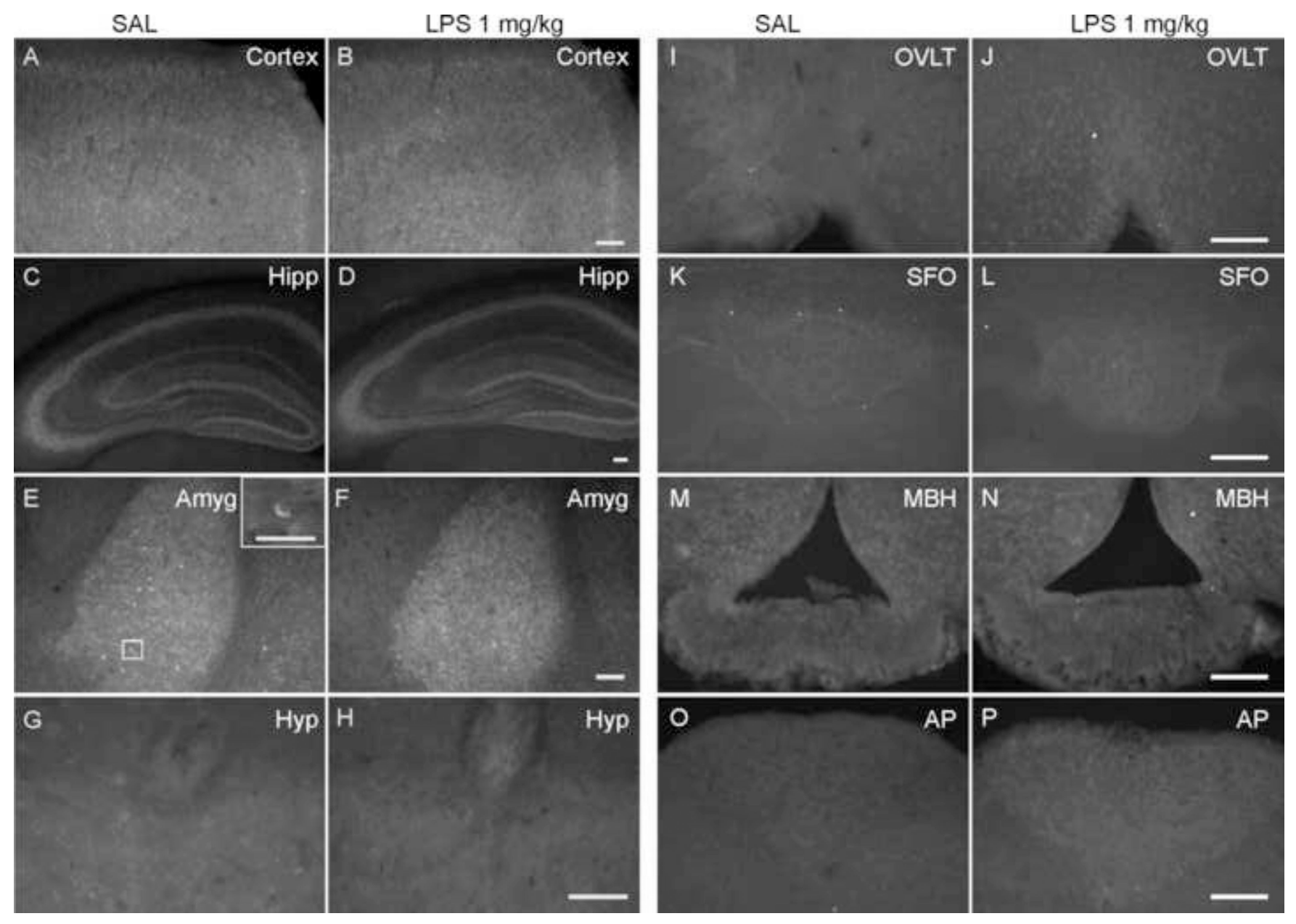

Figure 4.

Fluorescence micrographs of N-terminal $\mathrm{CB}_{1}$ immunoreactivity in the brain $24 \mathrm{~h}$ after saline or LPS treatment $(1 \mathrm{mg} / \mathrm{kg}$, i.p.). Dense fine fiber immunoreactivity was distributed in forebrain, especially cortex (image captured from cingulate and motor cortex) (A, B), hippocampus (Hipp; C, D) and basolateral nucleus of amygdala (Amyg; E, F).

Immunoreactive neurons (inset in panel $\mathrm{E}$ ), were also observed within these regions. In brainstem, there was some weak immunoreactivity found around the 4th ventricle $(G, H)$ and at the margin of hypoglossal nucleus adjoining the dorsal motor nucleus of the vagus (Hyp). However, no immunoreactivity was observed in CVOs (I \& J, vascular organ of the lamina terminalis [OVLT]; K \& L, subfornical organ [SFO]; M \& N, median eminence $[\mathrm{MBH}] ;$ O \& P, area postrema [AP]). Scale bars: $100 \mu \mathrm{m}(\mathrm{A}-\mathrm{F}, \mathrm{I}-\mathrm{P}), 50 \mu \mathrm{m}(\mathrm{G}, \mathrm{H}$ and inset in Panel E). 


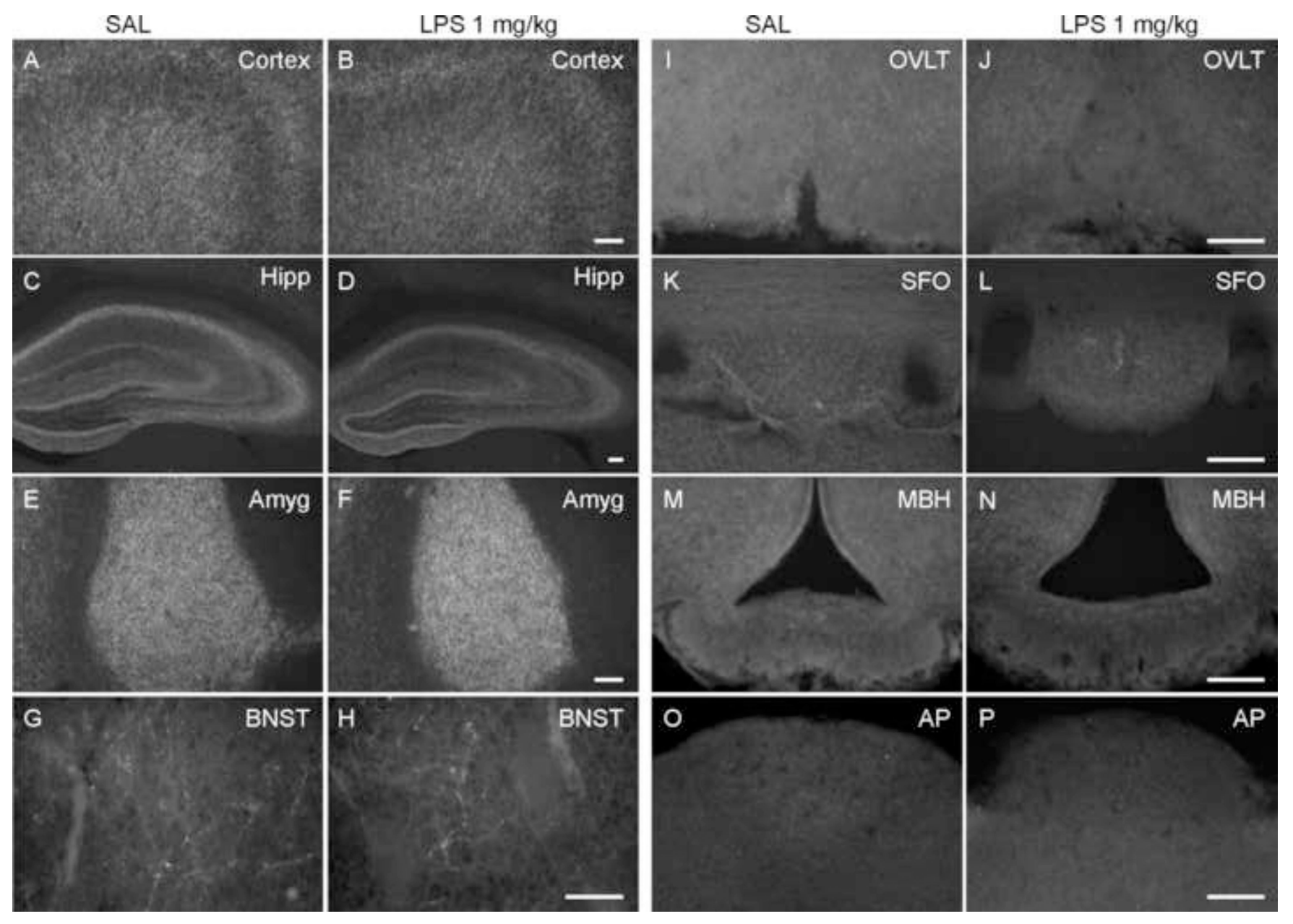

Figure 5.

Fluorescence micrographs of $\mathrm{C}$-terminal $\mathrm{CB}_{1}$ immunoreactivity in the brain 24 hours after saline or LPS treatment $(1 \mathrm{mg} / \mathrm{kg}$, i.p.). Dense fine fiber immunoreactivity was located in forebrain, especially cortex (image captured from cingulate and motor cortex) (A, B), hippocampus (Hipp; C, D) and basolateral nucleus of amygdala (Amyg; E, F). In hippocampus, the immunoreactivity in the LPS-treated group (D) was relatively weaker than the control group (C). In contrast to the images in Figure 6, the dorsal part of bed nucleus of the stria terminalis (BNST; G, H) only showed fine fiber immunoreactivity; there was no difference between LPS-treated and control animals. However, no immunoreactivity was observed in CVOs (I \& J, vascular organ of the lamina terminalis [OVLT]; K \& L, subfornical organ [SFO]; M \& N, median eminence [MBH]; O \& P, area postrema [AP]). Scale bars: $100 \mu \mathrm{m}(\mathrm{A}-\mathrm{F}, \mathrm{I}-\mathrm{P}), 50 \mu \mathrm{m}(\mathrm{G}, \mathrm{H})$. 


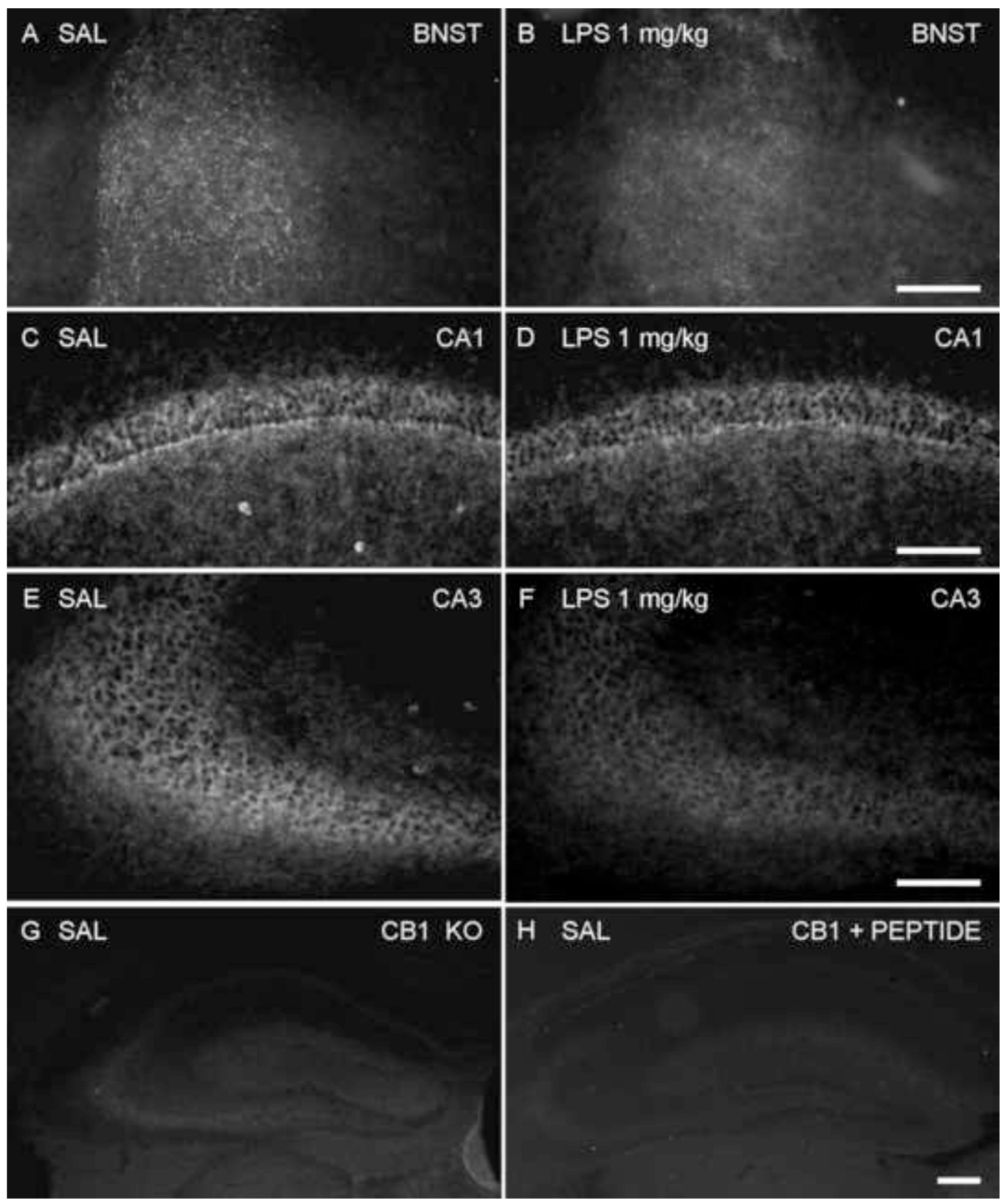

Figure 6.

Fluorescence micrographs of $\mathrm{N}$-terminal $\mathrm{CB}_{1}$ immunoreactivity in the brain $24 \mathrm{~h}$ after saline or LPS treatment $\left(1 \mathrm{mg} / \mathrm{kg}\right.$, i.p.). Twenty four hours after saline or LPS treatment, $\mathrm{CB}_{1}$ expression decreased in the dorsal part of BNST (A, B), the CA1 (C, D) and CA3 (E, F) regions of the hippocampus in LPS-treated mice. $(\mathrm{G}) \mathrm{N}$-terminal $\mathrm{CB}_{1}$ immunoreactivity in the hippocampus of a $\mathrm{CB}_{1}$ knockout mouse. $(\mathrm{H}) \mathrm{N}$-terminal $\mathrm{CB}_{1}$ immunoreactivity in hippocampus of CD1 mouse was absent when the antibody was preabsorbed with $10 \mu \mathrm{g} / \mathrm{ml}$ of the immunizing peptide. Scale bar: $100 \mu \mathrm{m}$. 

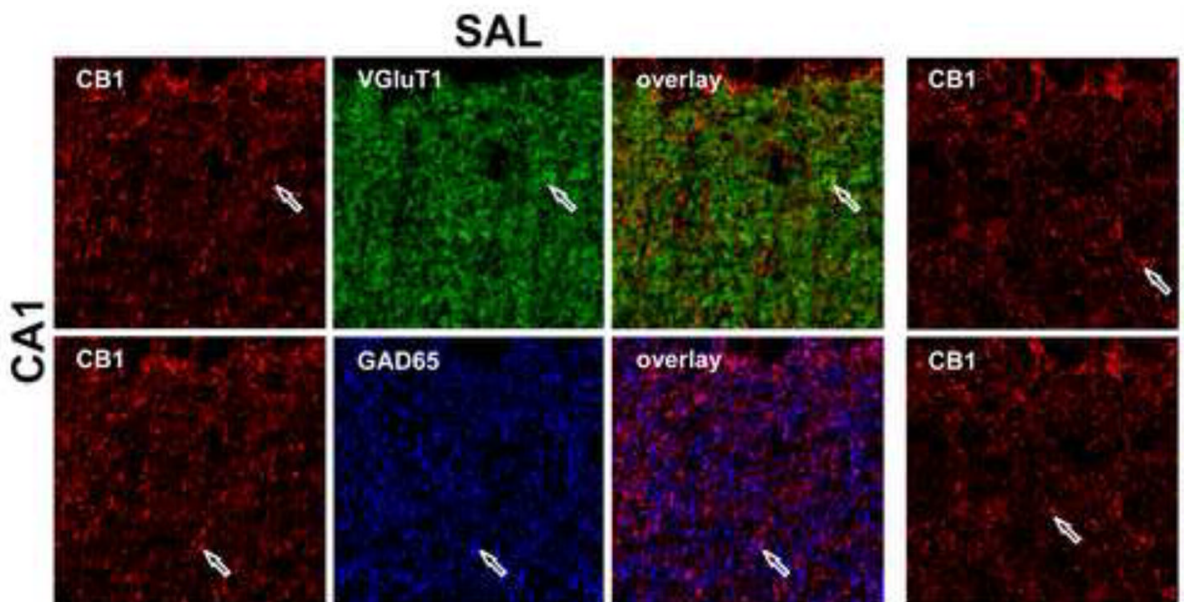

LPS $1 \mathrm{mg} / \mathrm{kg}$
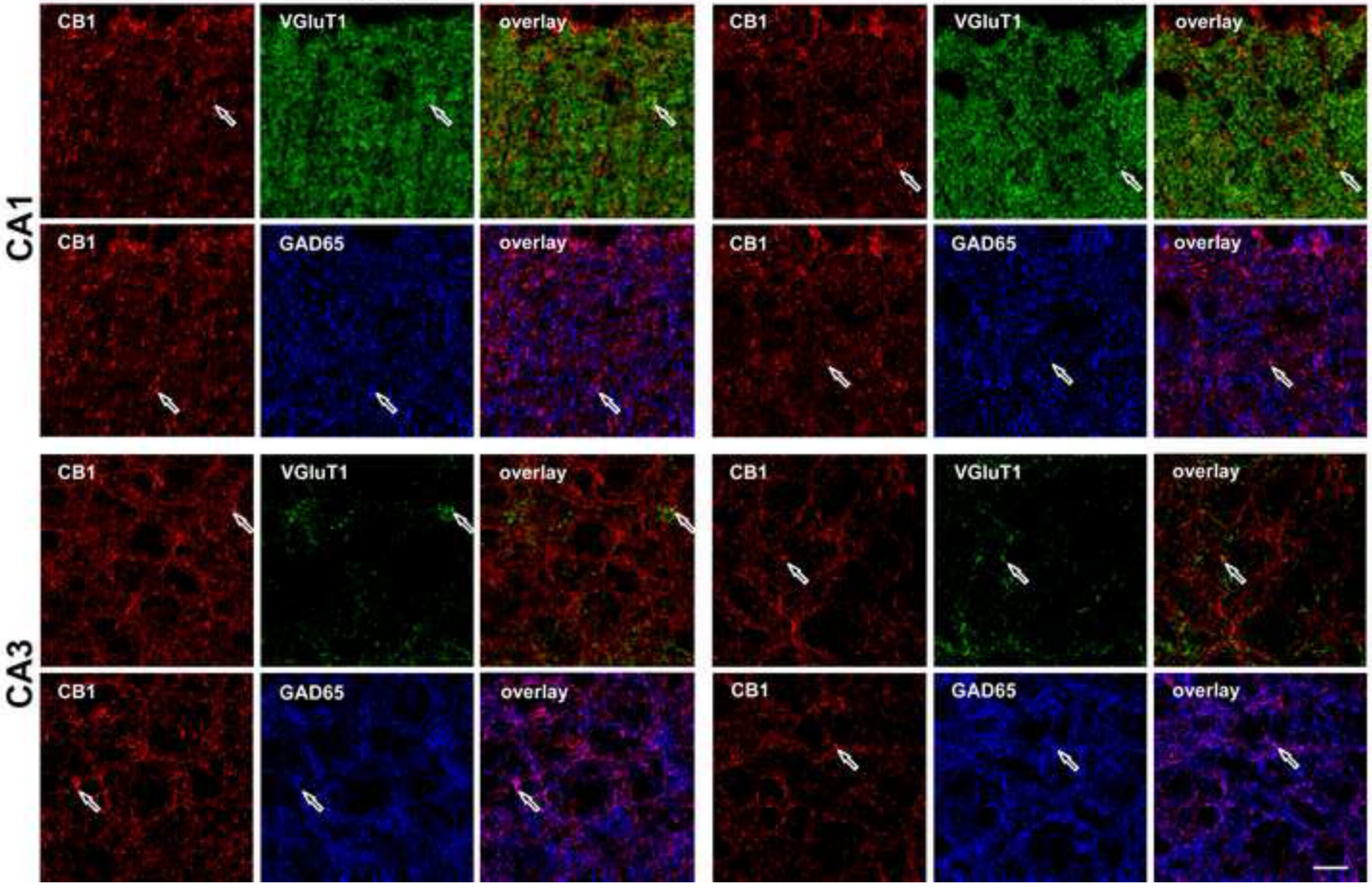

Figure 7.

Confocal images of the $\mathrm{CB}_{1}$ (red), VGluT1 (green) and GAD65 (blue) immunoreactivity in $\mathrm{CA} 1$ radiatum layer and $\mathrm{CA} 3$ pyramidal layer of the hippocampus. $\mathrm{CB}_{1}$ immunoreactivity was relatively low in both regions, especially in CA3 pyramidal layer, in the LPS-treated mice. The colocalization of CB1/VGluT1, and CB1/GAD65 was represented as yellow and purple colors, respectively in the overlay panel. Examples of specific sites of overlap are shown with arrows. Scale bar: $10 \mu \mathrm{m}$. 
A

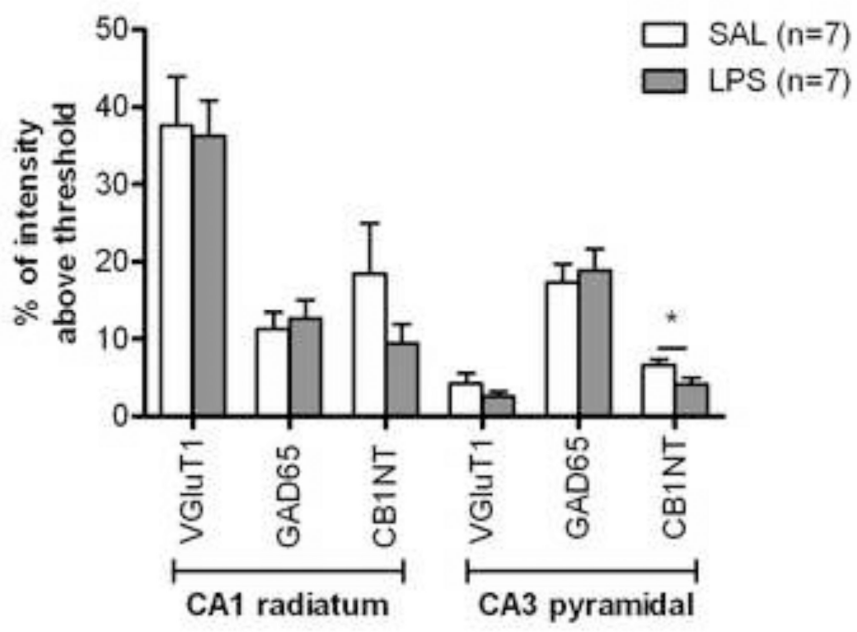

B

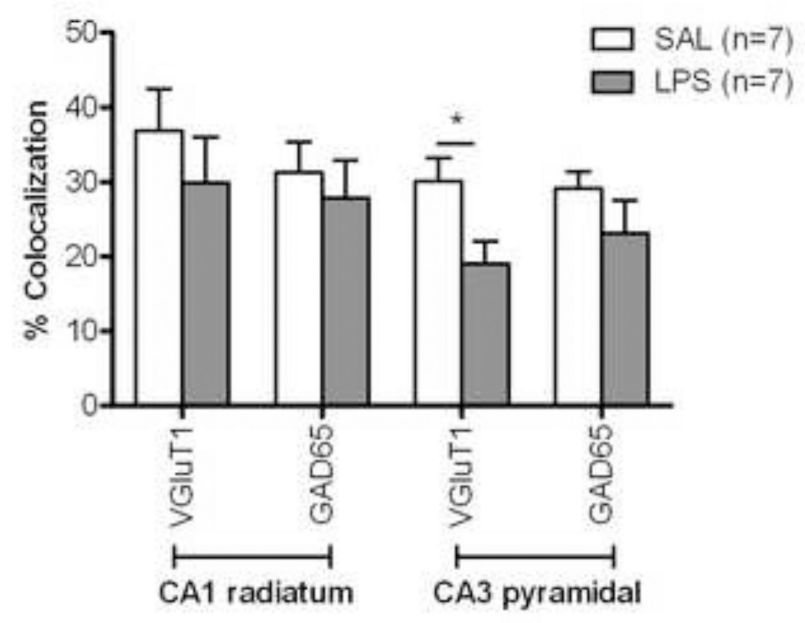

Figure 8.

Quantitative assessment of the distribution of $\mathrm{CB}_{1}$ in different nerve terminal populations in the hippocampus. Twenty four hours after treatment with saline or LPS $(1 \mathrm{mg} / \mathrm{kg}$, i.p. $), \mathrm{N}$ terminal $\mathrm{CB}_{1}$, VGluT1 and anti-GAD65 immunoreactivity were evaluated from confocal images. (A) In CA1, the immunoreactivity of these three antibodies was similar in treated and control animals. However, in $\mathrm{CA} 3, \mathrm{CB}_{1}$ immunoreactivity was significantly reduced in LPS-treated animals. (B) Analysis of the colocalization of the different antibodies indicated that the major changes of $\mathrm{CB}_{1}$ distribution in $\mathrm{CA} 3$ region were found on glutamatergic nerve terminals rather than on GABAergic terminal. ${ }^{*} \mathrm{p}<0.05$. 
Table 1

$\mathrm{CB}_{1}$ immunoreactivity in individual brain region. ++++ , high expression; + , low expression; \pm , punctate pattern rather than fine fiber pattern. For abbreviations, see list of abbreviations.

\begin{tabular}{|c|c|c|c|c|}
\hline \multirow[t]{2}{*}{ Brain region } & \multicolumn{2}{|c|}{$\mathrm{CB}_{1}$ C-terminal } & \multicolumn{2}{|c|}{$\mathrm{CB}_{1}$ N-terminal } \\
\hline & SAL & LPS & SAL & LPS \\
\hline Cortex & ++++ & ++++ & ++++ & ++++ \\
\hline LS & + & + & \pm & \pm \\
\hline \multicolumn{5}{|l|}{$\mathrm{ACB}$} \\
\hline Core & + & + & \pm & \pm \\
\hline Shell & + & + & \pm & \pm \\
\hline \multicolumn{5}{|l|}{ BNST } \\
\hline Dorsal part & + & + & +++ & ++ \\
\hline Ventral part & + & \pm & ++ & ++ \\
\hline MPA & \pm & \pm & - & - \\
\hline $\mathrm{MnPO}$ & - & \pm & - & - \\
\hline VMPO & - & - & - & - \\
\hline \multicolumn{5}{|l|}{ Amygdala } \\
\hline $\mathrm{CeC}$ & + & + & \pm & \pm \\
\hline BLA & ++++ & ++++ & ++++ & ++++ \\
\hline BMA & +++ & +++ & +++ & +++ \\
\hline $\mathrm{ACo}$ & +++ & +++ & ++ & ++ \\
\hline \multicolumn{5}{|l|}{ Hippocampus } \\
\hline CA1 & ++++ & +++ & ++++ & +++ \\
\hline CA3 & ++++ & +++ & ++++ & +++ \\
\hline DG & ++++ & ++++ & ++++ & ++++ \\
\hline \multicolumn{5}{|l|}{ Thalamus } \\
\hline PVT & - & - & \pm & - \\
\hline \multicolumn{5}{|l|}{ Hypothalamus } \\
\hline PVN & - & - & \pm & \pm \\
\hline $\mathrm{PeV}$ & - & - & \pm & \pm \\
\hline SON & \pm & \pm & - & - \\
\hline DMH & - & - & - & - \\
\hline $\mathrm{LH}$ & \pm & \pm & \pm & \pm \\
\hline VMH & - & - & - & - \\
\hline ARC & - & - & - & - \\
\hline PAG & - & - & - & - \\
\hline $\mathrm{SN}$ & ++++ & ++++ & ++++ & ++++ \\
\hline NTS & - & - & - & - \\
\hline $\mathrm{DMN}$ & - & - & - & - \\
\hline $12 \mathrm{~N}$ & + & + & \pm & \pm \\
\hline \multicolumn{5}{|l|}{ CVOs } \\
\hline OVLT & - & - & - & - \\
\hline
\end{tabular}




\begin{tabular}{llllll}
\hline \multirow{2}{*}{ Brain region } & \multicolumn{2}{c}{$\mathrm{CB}_{1}$ C-terminal } & & \multicolumn{2}{c}{$\mathrm{CB}_{1}$ N-terminal } \\
\cline { 2 - 3 } \cline { 5 - 6 } & $\mathrm{SAL}$ & LPS & & SAL & LPS \\
\hline SFO & - & - & - & - \\
$\mathrm{ME}$ & - & - & - & - \\
$\mathrm{AP}$ & - & - & - & - \\
\hline
\end{tabular}

